\title{
ArcheoSciences
}

Revue d'archéométrie

33 (suppl.) | 2009

Mémoire du sol, espace des hommes

\section{A Survey in the Park: methodological and practical problems associated with geophysical investigation in a late Victorian municipal park}

\section{Andrew Parkyn}

\section{OpenEdition}

\section{Journals}

Electronic version

URL: https://journals.openedition.org/archeosciences/1620

DOI: 10.4000/archeosciences. 1620

ISBN: 978-2-7535-1599-4

ISSN: $2104-3728$

Publisher

Presses universitaires de Rennes

\section{Printed version}

Date of publication: 30 October 2009

Number of pages: 229-231

ISBN: 978-2-7535-0943-6

ISSN: $1960-1360$

\section{Electronic reference}

Andrew Parkyn, "A Survey in the Park: methodological and practical problems associated with geophysical investigation in a late Victorian municipal park", ArcheoSciences [Online], 33 (suppl.) | 2009, Online since 30 October 2011, connection on 01 February 2022. URL: http://

journals.openedition.org/archeosciences/1620 ; DOI: https://doi.org/10.4000/archeosciences.1620 


\title{
A Survey in the Park: methodological and practical problems associated with geophysical investigation in a late Victorian municipal park
}

\author{
Andrew PARKYN*
}

Key words: Municipal parks, High resolution survey, Earth resistance, Gradiometer \& Planting.

The survey of Pudsey Park in West Yorkshire is the first of its kind; the park is a late Victorian municipal park that has continued to evolve over the last 120 years. The park fills a 2.8 hectare site in the middle of the town centre and represents one part of the massive expansion of many Northern England towns during the Industrial Revolution. The newfound wealth from the textile industry helped fund the acquisition of a site and its development to improve the health and morals of the working classes during the Victorian period.

Parks acted as external displays of civic pride and were a way for wealthy benefactors to show their generosity by donating money for park features. Pudsey, for example, featured a drinking fountain and bandstand bequeathed to the people of Pudsey by some of the wealthier townspeople.

The main aim of the survey was to chart the park's development over time and look to improve the confidence in using geophysics as a precursor to archaeological garden excavations or as a stand-alone method of investigation. The project also aimed to identify a suitable sampling strategy for studying future park and garden sites that recorded current and previous designs.

Documentary research indicated the park's design has changed over time and so has the demand on the park from the local population. The Victorian park was a place to take in the air whilst admiring the planting of many new and exotic species that were introduced from the colonies during the Victorian period. There were areas to promenade and places to rest undercover and parks also provided open areas for meetings. Fountains and arbours were built to provide water and shelter whilst crown green bowling provided a form of exercise and the lake a place to admire the wildlife. Several of these features still remain in the park but most are later redevelopments (see Fig. 1) or have been removed entirely. The park, like so many of its kind, has become more simplified in part due to cost but also the declining importance placed upon open spaces within towns. The park today is often used as a short cut or a place to take children and walk dogs as the park's role of providing the only means of open space to meet people and admire nature is in decline.

Previous discussions by garden archaeologists and geophysicists during the course of the last decade have focused mainly on small privately owned gardens where designs and planting schemes could be changed at a whim. This project however looks at a larger area of land where any alterations have required considerably more planning and expense. Previous work using geophysics in gardens was considered and a pilot study was carried out in the park. The informa-

* PhD. student Division of Archaeological, Geographical and Environmental Sciences, University of Bradford, Bradford, West Yorkshire, BD71DP, UK. (a.k.parkyn@bradford.ac.uk) 


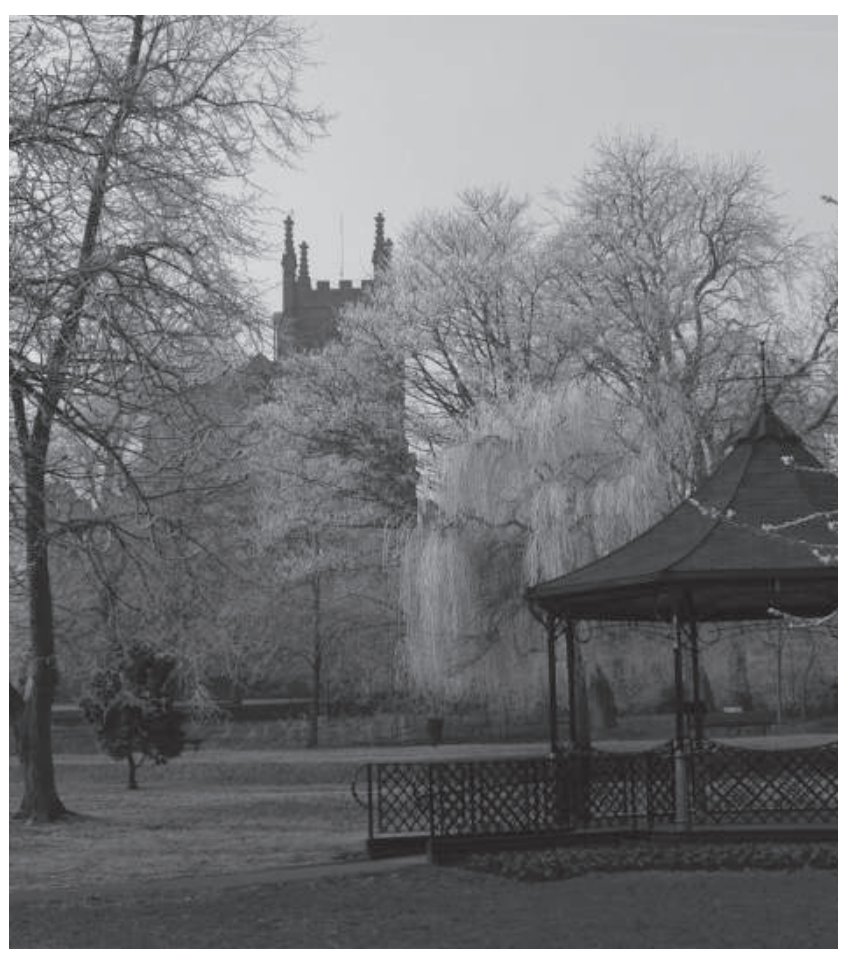

Figure 1: Showing the modern bandstand and planting schemes.

tion gathered indicated that a high-resolution survey should be implemented on the 2.8 hectare site.

The initial-desk based assessment of late Victorian Municipal parks as a whole indicated the broad range of features that were often found in parks. Ranging from ephemeral park and garden features, such as flowerbeds, to shelters and lakes. However Pudsey Park seemed to have little evidence for these features above ground so it was of interest to see what features would be identified. Therefore a multimethod geophysical survey of this late Victorian Municipal park was carried out using earth resistance and fluxgate gradiometer instruments. A detailed topographic survey of the park was also produced to act as a framework for a GIS database and to reconfirm signal responses of many of the modern park features.

Earth resistance data was collected with a twin probe array with multiple probe separations at $0.25 \mathrm{~m}, 0.5 \mathrm{~m}$ and $1 \mathrm{~m}$ on a $1 \mathrm{~m}$ frame, with a sampling interval of $0.5 \mathrm{~m}$ and traverse intervals of $1 \mathrm{~m}$. For the $0.25 \mathrm{~m}$ electrode separation the resulting spatial resolution was hence $0.5 \mathrm{~m} \times 0.25 \mathrm{~m}$. Gradiometer data was collected with a Geoscan FM256 using a sampling interval of $0.125 \mathrm{~m}$ and a $0.5 \mathrm{~m}$ traverse interval.

The survey provided highly detailed but complicated data sets (see Fig. 2 and 3); areas of the park have had several re-designs, where the modern scheme often masked previous

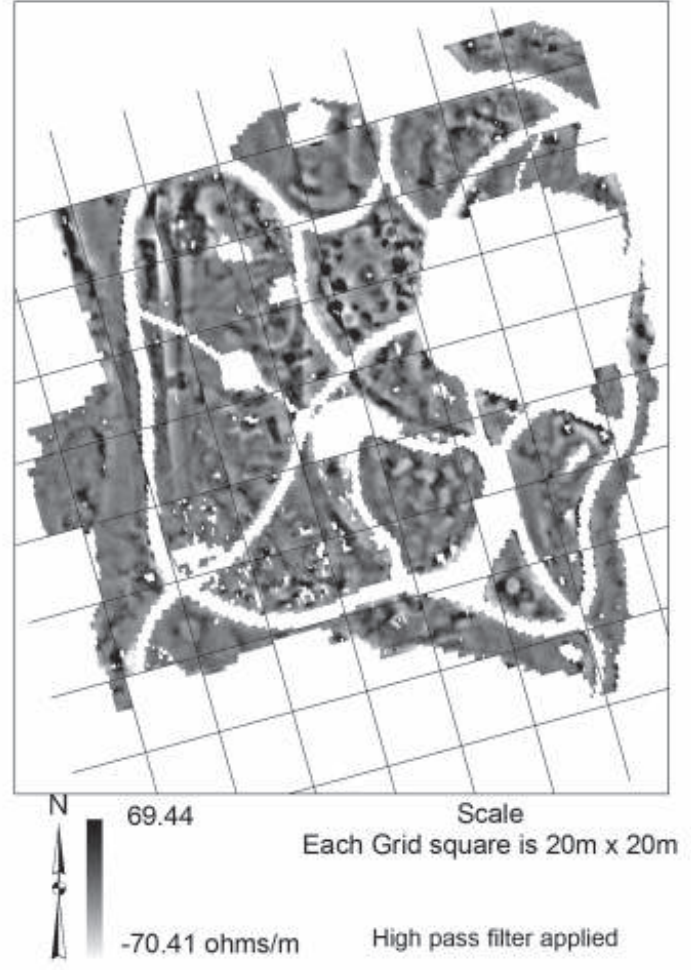

Figure 2: Showing the processed $0.25 \mathrm{~m}$ probe separation resistivity data.

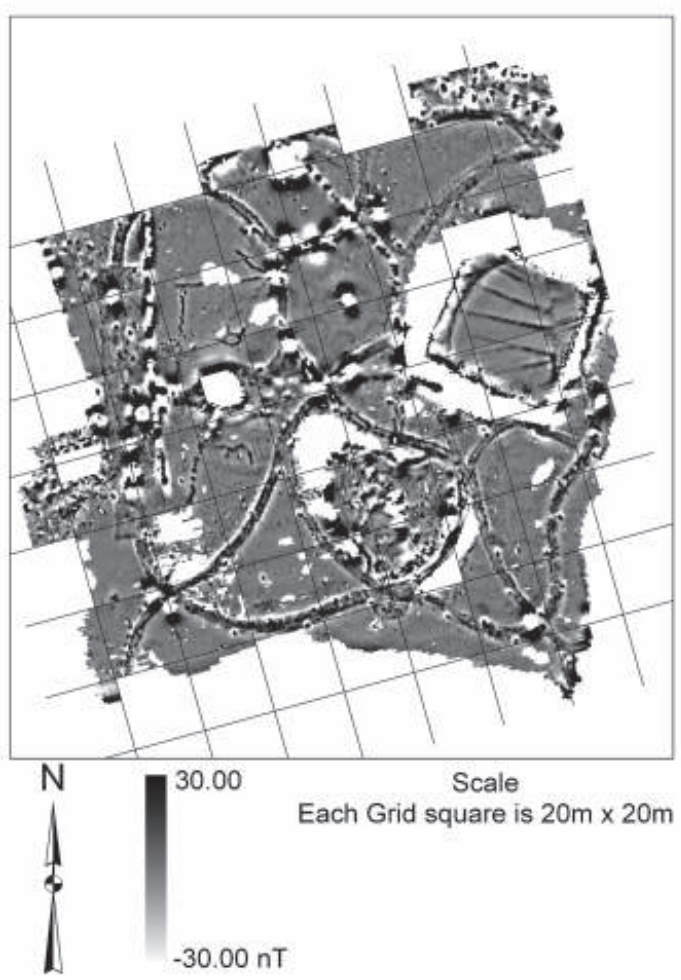

Figure 3: Showing the processed fluxgate gradiometer data. 
designs. The use of multiple electrode separations allowed for an approximate depth analysis and aided interpretation by filtering out some of the modern planting schemes with the wider probe separations. However the $0.25 \mathrm{~m}$ probe separation produced the most defined data with the greatest level of information due to the increased spatial resolution. This probe separation with close $0.5 \mathrm{~m}$ sampling intervals are essential for the many near surface features that are of interest to garden archaeologists.

The survey was hampered in many ways by the modern design, densely planted borders and structures meant some areas were inaccessible whilst the daily interest from the general public sometimes created its own unique set of problems. The project allowed for the inclusion of several sets of unusual sources of secondary supporting evidence. Newspapers provided enlightening and sometimes entertaining sources of information even when the articles may not have specifically related to the layout of the park. Verbal accounts of local people also provided a fascinating insight into the park's history and use. However, many of the most recent feature locations were still open to debate and these could be mapped precisely through the geophysics data.

The survey validates the importance of high-resolution survey in the study of parks and gardens and also acts as a reference data set for future work where poorer documentation hinders interpretation. The results show that with careful interpretation it is possible to separate individual garden phases over time even when masked by modern planting. The geophysics data, together with the accompanying GIS database produce a unique and detailed picture of a Victorian park from its inception through the course of 120 years of development on a discrete parcel of land within a West Yorkshire town. 